\title{
KOMPOSISI HASIL TANGKAPAN SAMPINGAN (BYCATCH) PERIKANAN PUKAT UDANG SKALA KECIL DI PERAIRAN LAUT PASAR BANTAL KABUPATEN MUKOMUKO
}

\author{
Oleh \\ Bambang Rainaldi, Zamdial, Dede Hartono \\ Program Studi IImu Kelautan, Fakultas Pertanian, Universitas Bengkulu \\ Email :b4mb4ngr4in4ldy@gmail.com \\ Received March 2017 Accepted April 2017
}

\begin{abstract}
ABSTRAK
Pukat udang adalah alat tangkap yang dioperasikan secara aktif dengan cara ditarik oleh perahu. Hasil tangkapan sampingan adalah bagian dari hasil tangkapan yang terdiri dari organisme laut yang bukan merupakan target penangkapan utama. Penelitian ini bertujuan untuk menganalisis komposisi hasil tangkapan sampingan (bycatch) alat tangkap pukat udang skala kecil di perairan laut Pasar Bantal Kabupaten Mukomuko. Penelitian ini dilaksanakan pada bulan Juli sampai dengan bulan September 2016 di Desa Pasar Bantal Kecamatan Teramang Jaya Kabupaten Mukomuko. Penelitian ini dilakukan dengan metode survei. Untuk kepentingan pengumpulan data primer maka dilakukan observasi langsung ke lapangan mengikuti operasi penangkapan bersama nelayan dengan menggunakan alat tangkap pukat udang. Berdasarkan hasil tangkapan selama penelitian dengan 6 kali hauling yaitu jumlah hasil tangkapan utama sebanyak 4 spesies udang dengan berat total $35,91 \mathrm{~kg}(27,15 \%)$ yang didominasi oleh udang kerosok (Parapenaeopsis sculptilis) $13,74 \mathrm{~kg}$. Jumlah hasil tangkapan sampingan yang bernilai ekonomis tinggi sebanyak 6 spesies dengan berat total 44,01 $\mathrm{kg}(33,28 \%)$ didominasi oleh layur (Trichiurus savala) sebesar $15,81 \mathrm{~kg}$. Sedangkan untuk jumlah hasil tangkapan sampingan yang bernilai ekonomis rendah terdapat sebanyak 18 spesies dengan berat total $52,3 \mathrm{~kg}(39,55 \%)$ didominasi oleh senangin (Eleutheronema tetradactyum) $9,16 \mathrm{~kg}$.
\end{abstract}

Kata kunci: Pukat udang, tangkapan sampingan, ekonomis tinggi, Bantal..

\section{ABSTRACT}

Shrimp trawl fishing gear which is operated by actively taking pulled by a boat. The result of bycatch is part of the catch consisting of marine organisms which are not is main target of arrests. The aimed of this study to analyze the composition of bycatch of the small scale shrimp trawl in the Pasar Bantal waters, Mukomuko regency. The research was conducted in July to September 2016 village Pasar Bantal Subdistrict Teramang Jaya Mukomuko. Research was conducted by survey method. For the purposes of primary data collection is carried directly to the field observations following the arrest operation with the fishermen using shrimp trawl fishing gear. Based on the catch during the study with six times hauling, the amount of main catch as many as four major species of shrimp with a total weight of $35.91 \mathrm{~kg}(27.15 \%)$, which is dominated by kerosok shrimp (Parapenaeopsis sculptilis) $13.74 \mathrm{~kg}$. Amount of bycatch that have a high economic value as much as 6 species with a total weight of 44.01 
$\mathrm{kg}(33.28 \%)$ is dominated by layur (Trichiurus savala) amounted to $15.81 \mathrm{~kg}$. As for the number of results bycatch low economic value as many as 18 species with a total weight of $52.3 \mathrm{~kg}(39.55 \%)$ is dominated by Senangin (Eleutheronema tetradactyum) $9.16 \mathrm{~kg}$.

Keywords: Shrimp trawl, bycatch, high economic value, Bantal.

\section{PENDAHULUAN}

Hasil tangkapan sampingan atau disingkat HTS telah menjadi permasalahan dan isu perikanan terpenting dunia sejak tahun 1990-an. Hal ini dikarenakan peningkatan jumlah hasil tangkapan sampingan menjadi salah satu penyebab penurunan stok ikan yang dapat mengancam keberlanjutan perikanan dunia. Secara umum diketahui hampir semua kegiatan perikanan tangkap menghasilkan hasil tangkapan sampingan, namun beberapa jenis alat tangkap khususnya pukat udang (shrimp trawl), diketahui memberikan kontribusi hasil tangkapan sampingan yang lebih besar dibandingkan alat tangkap lainnya. Hal ini terjadi karena udang dan ikan menghuni habitat yang sama dan sifat pukat udang itu sendiri yang memang tidak selektif. Pukat udang menggunakan mata jaring dibagian kantong (cod-end) yang relatif kecil sehingga banyak jenis-jenis organisme laut lainnya ikut tertangkap termasuk ikan-ikan juvenil. Organisme-organisme lainnya dan ikan-ikan juvenil tersebut tidak termasuk kedalam tujuan penangkapan utama (non-targeted species) atau disebut dengan bycatch.

Hasil survei pendahuluan yang dilakukan oleh peneliti, alat tangkap pukat udang yang dioperasikan di perairan Desa Pasar Bantal tergolong pada jenis alat tangkap trawl, tetapi yang membedakannya yaitu ukuran alat tangkap yang relatif kecil dari pada yang dioperasikan oleh kapal-kapal besar lainnya atau nelayan setempat menyebutnya dengan nama pukat udang (mini traw). Alat tangkap pukat udang (mini traw) target tangkapan utamanya adalah udang. Selain udang sebagai target tangkapan utama ada berbagai jenis hasil tangkapan sampingan berupa ikan-ikan juvenil demersal dan biota-biota lainnya yang ikut tertangkap (bycatch) yang belum diketahui komposisi hasil tangkapannya. Dari uraian diatas penulis ingin melakukan penelitian tentang komposisi hasil tangkapan sampingan (bycatch) perikanan pukat udang skala kecil di perairan laut Pasar Bantal Kabupaten Mukomuko. Penelitian ini terwujud atas kerjasama program penelitian dana hibah bersaing dari Kementerian Riset Teknologi dan Pendidikan Tinggi (KEMENRISTEKDIKTI) diterima oleh salah satu kelompok dosen Program Studi IImu Kelautan Universitas Bengkulu.

\section{MATERI DAN METODE}

Penelitian ini dilaksanakan pada bulan Juli sampai dengan bulan September 2016 di Desa Pasar Bantal Kecamatan Teramang Jaya Kabupaten Mukomuko.

\section{Metode Pengoperasian Pukat Udang}

Menurut Khaerudin (2006) Pengoperasian pukat udang diperairan laut Pasar Bantal Kabupaten Mukomuko umumnya diasumsikan dilakukan pada 
malam hari atau siang hari, tergantung target utama penangkapan. Pengoperasian alat tangkap pukat udang pada saat penelitian melalui beberapa tahap, yaitu tahap persiapan, tahap pencarian fishing ground, tahap operasi penangkapan (setting,towing atau penarikan jaring dan hauling atau pengangkatan jaring) dan tahap penanganan hasil tangkapan. Selama proses penelitian dilapangan, penulis melakukan 3 kali trip penangkapan dengan 6 kali setting dan hauling. Trip penangkapan pertama yaitu pada hari minggu, 24 Juli 2016 dengan 1 kali hauling, Trip penangkapan ke dua pada hari senin 8 Agustus 2016 dengan 2 kali hauling, trip penangkapan ke tiga pada tanggal 4 dan 5 September 2016 dengan 3 kali hauling di Perairan Desa Pasar Bantal Kecamatan Teramang Jaya Kabupaten Mukomuko.

Ada beberapa tahap Dalam pengoperasian pukat udang yaitu ; (1) Tahap persiapan ; (2) Tahap pencaharian fishing ground ; (3) Tahap operasi penangkapan yang meliputi setting, towing dan hauling; dan (4) Penanganan hasil tangkapan

\section{Identifikasi Hasil Tangkapan}

Identifikasi hasil tangkapan pukat udang di Desa Pasar Bantal Kabupaten Mukomuko dengan menggunakan buku identifikasi ikan yaitu ; FAO (2012), Nelson (1984) dan FAO (1974).

Identifikasi ikan hasil tangkapan pukat udang dilakukan dilokasi penelitian untuk jenis-jenis hasil tangkapan yang tidak dapat diidentifikasi secara langsung maka akan diawetkan, dan selanjutnya akan diidentifikasi dilabolatorium Perikanan,Universitas Bengkulu.

\section{Komposisi Hasil Tangkapan}

Hall (1999) membedakan kategori hasil tangkapan yaitu hasil tangkapan utama, dan hasil tangkapan sampingan (bycatch). Hasil tangkapan sampingan dikelompokkan menjadi tiga kategori yaitu hasil tangkapan sampingan yang bernilai ekonomis tinggi, hasil tangkapan sampingan yang bernilai ekonomis rendah dimanfaatkan dan hasil tangkapan sampingan yang dibuang ke laut.

\section{Komposisi Hasil Tangkapan Sampingan}

\section{Hasil Tangkapan Sampingan Ekonomis Tinggi}

Hasil tangkapan sampingan yang bernilai ekonomis tinggi yaitu hasil tangkapan sampingan yang diperoleh, nilai jualnya di pasaran relatif tinggi . Contohnya seperti cumi-cumi, sotong, kepiting, rajungan.

\section{Hasil Tangkapan Sampingan Ekonomis Rendah}

Hasil tangkapan sampingan ekonomis rendah yaitu hasil tangkapan sampingan yang diperoleh, nilai jualnya dipasaran relatif rendah. Contohnya seperti ikan buntal, pepetek, baji-baji.

Hasil analisis komposisi ikan tangkapan pukat udang selanjutnya dinyatakan dalam persentase komposisi dengan menggunakan tabel, grafik dan diagram Pie (Wahju, dkk 2008)

\section{Gambaran Umum}

\section{HASIL DAN PEMBAHASAN}

Secara administratif Desa Pasar Bantal terletak di Kecamatan Teramang Jaya Kabupaten Mukomuko Provinsi Bengkulu. Jarak tempuh dari ibu kota Provinsi yaitu $250 \mathrm{~km}$ dengan waktu tempuh 6-7 jam baik menggunakan 
kendaraan bermotor maupun mobil dan jarak tempuh dari ibu kota Kabupaten yaitu kota Mukomuko sejauh $60 \mathrm{~km}$ selama 2 jam perjalanan menggunakan kendaraan bermotor maupun mobil. Jarak tempuh ke pusat kecamatan hanya 1 menit. Panjang garis pantai Kecamatan Teramang Jaya yaitu $34,33 \mathrm{~km}$ atau luas laut teritorial $254,30 \mathrm{~km}^{2}$. Luas area $36,060000 \mathrm{Ha}$ dengan tekstur tanah berpasir secara umum berada dikoordinat 101.34845 BT / -2.756891 LS berhadapan langsung dengan Samudera Hindia.

\section{Unit Penangkapan}

\section{Kapal}

Ada dua kategori jenis kapal yang digunakan Nelayan di Desa Pasar Bantal Kecamatan Teramang Jaya yaitu (1) kapal jokong atau perahu tempel gunanya untuk menjaring ikan, (2) kapal pukat udang khusus untuk menangkap udang dengan ukuran kapal secara umum 5 GT . Mesin kapal yang digunakan yaitu mesin diesel dengan ukuran 23 PK yang diletakkan di bagian kabin kapal. Harga mesin diesel untuk kapal pukat udang Rp 9.000.000,- per unit dan jika di nominalkan harga untuk 1 unit kapal lengkap dengan mesinnya yaitu sekitar Rp 90.000.000,-. Kapal pukat udang di Pasar Bantal secara umum jenisnya sama,hanya pemilik setiap kapal supaya terlihat berbeda dengan kapal-kapal nelayan lainnya maka di beri nomor dan warna yang bervariasi pada setiap kapal. Panjang total kapal pukat udang yaitu 12 meter dan lebar 3 meter.

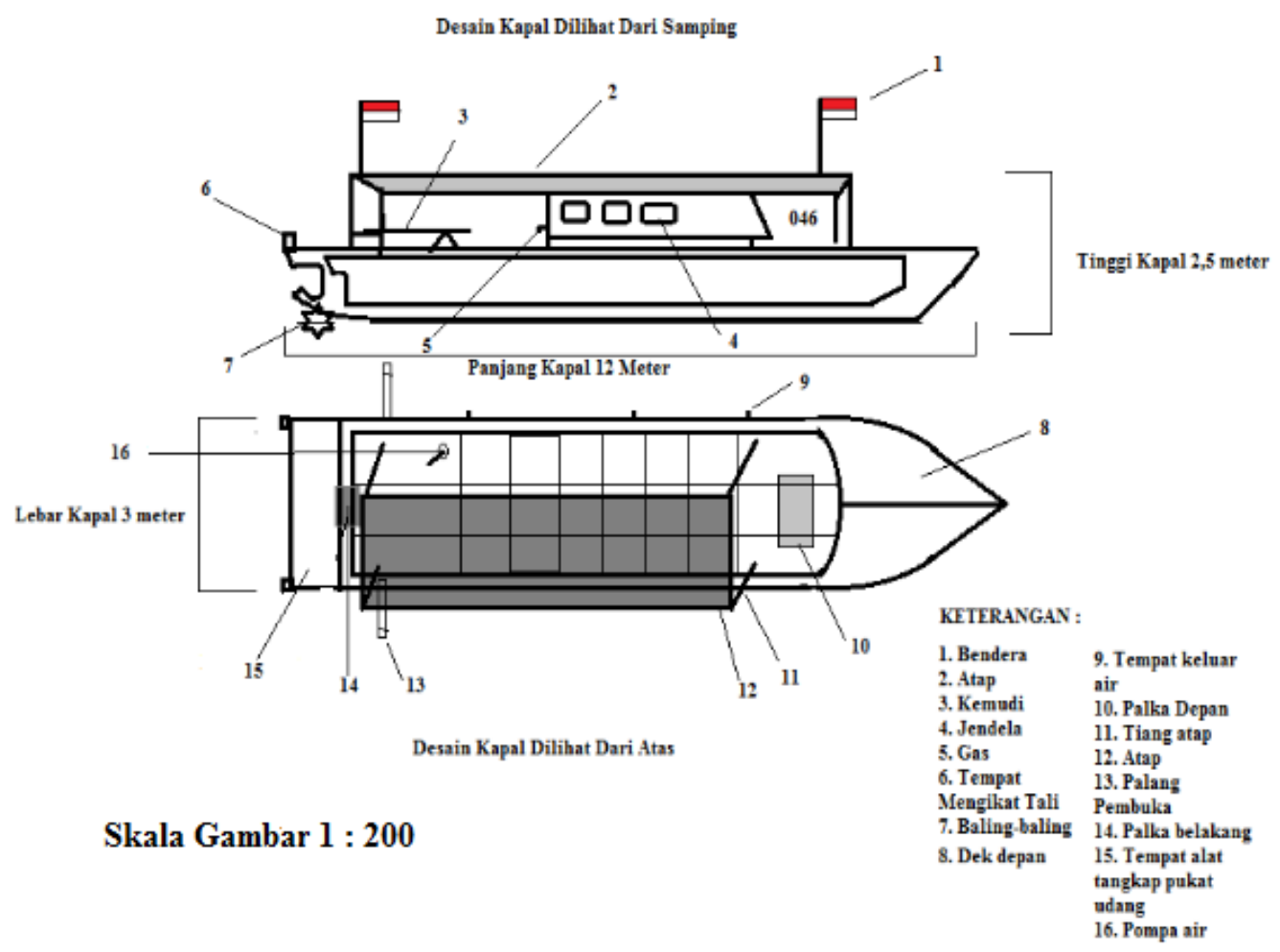

Gambar 1. Kontruksi Kapal Pukat Udang Mini Trawl (Data Primer)

\section{Alat Tangkap}

Berdasarkan pengamatan langsung dilapangan dan wawancara dengan nelayan Desa Pasar Bantal, secara umum Konstruksi alat tangkap pukat udang (mini trawl) yaitu sebagai berikut : 


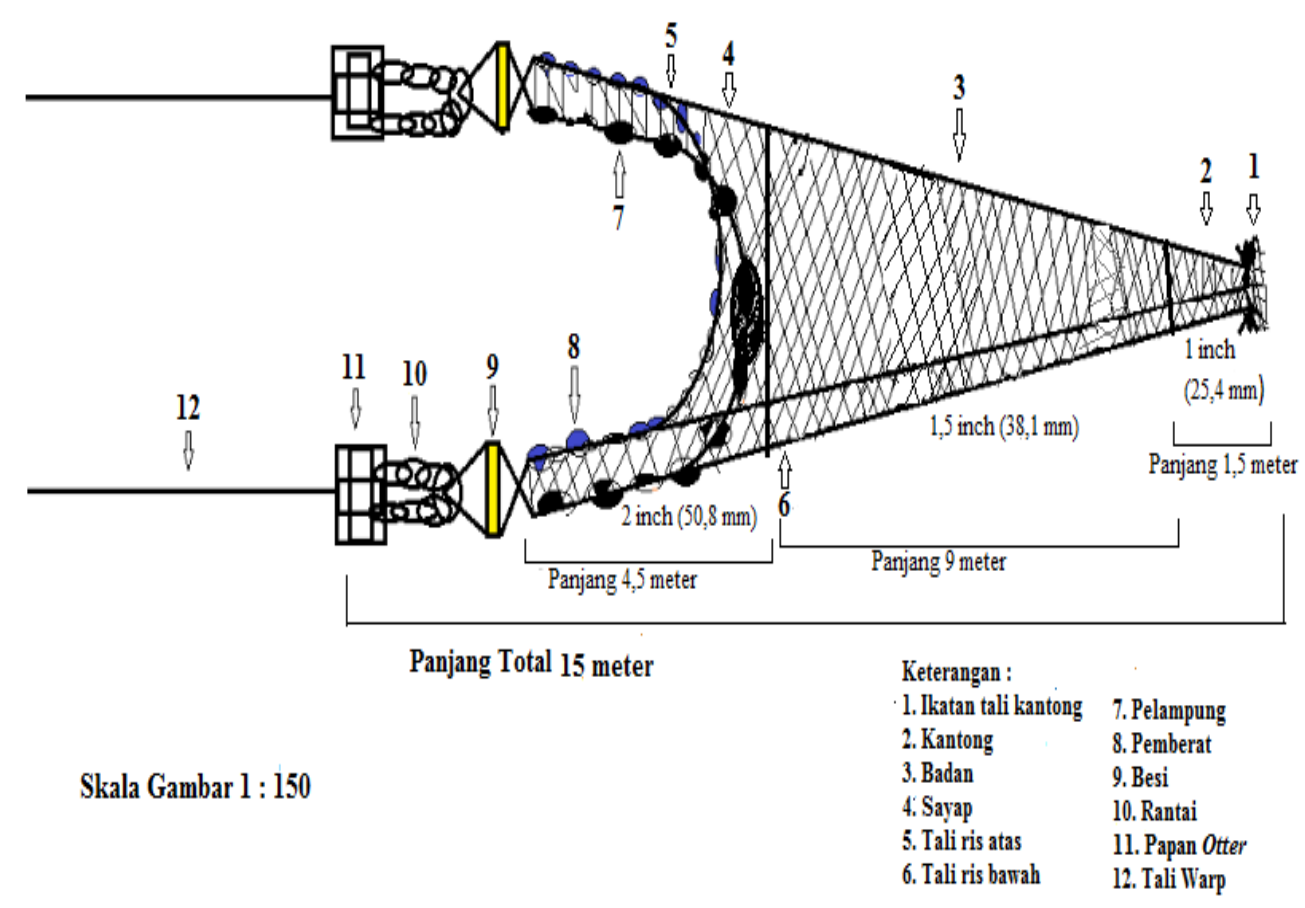

Gambar 2. Kontruksi pukat udang (data primer)

Dari gambar kontsruksi pukat udang diatas dapat penulis jelaskan bahwa bagian-bagian dari pukat udang (mini trawl) yaitu :

(1) Ikatan Tali Kantong

Pada bagian ujung kantong terdapat ikatan kantong, berfungsi sebagai menahan tutupan kantong supaya hasil tangkapan tidak keluar dari kantong. Ketika proses pengangkatan pukat ke atas kapal, bagian ikatan kantong dibuka supaya hasil tangkapan yang didapat dengan mudah untuk dikeluarkan diatas kapal. Biasanya ikatan kantong berbahan tali yang ukurannya relatif kecil dari pada tali utama (bridle line).

(2) Kantong (cod end)

Pada bagian kantongberfungsi sebagai menampung hasil tangkapan berupa udang dan ikan-ikan lainnya. Ukuran mata jaring (mesh size) pada bagian ini biasanya yang paling kecil yaitu $25,4 \mathrm{~mm}$ atau 1 inchi dengan panjang kantong 1,5 meter. Bahan jaring terbuat dari polyethylene (PE).

(3) Badan (belly)

Pada bagian badan berfungsi sebagai pengurung hasil tangkapan yang telah digiring oleh sayap, penghubung antarabagian kantong ke bagian sayap. ukuran mata jaring (mesh size) pada bagian badan yaitu $38,1 \mathrm{~mm}$ atau 1,5 inchi Dengan panjang 9 meter.

(4) Sayap (wing)

Pada bagian sayap berfungsi sebagai penggiring hasil tangkapan supaya masuk kedalam badan jaring. Sayap terdiri atas sayap kanan dan sayap kiri, masing-masing terdiri atas sayap atas (upper wing) dan sayap bawah (lower wing). Kedua sayap membentuk mulut jaring yang terdiri atas mulut atas (head line) yang diikatkan tali ris atas (head rope) sebagai tempat pelampung dan mulut bawah (ground line) yang diikatkan tali ris bawah (ground rope) yang 
diberi pemberat. Ukuran mata jaring (mesh size) yaitu 50,8 $\mathrm{mm}$ atau 2 inchi dengan panjang 4,5 meter.

(5) Tali Ris Atas

Tali ris bagian atas terbuat dari bahan polyethylene (PE) Multifilament dengan diameter $4 \mathrm{~mm}$ dan panjang $10,6 \mathrm{~m}$ serta warna biru.

(6) Tali Ris Bawah

Tali ris bagian atas terbuat dari bahan Manila hemp dengan diameter 10 $\mathrm{mm}$ dan panjang 14,6 $\mathrm{m}$ serta berwarna biru.

(7) Pelampung

Pelampung berfungsi sebagai penahan/pengambang supaya sayap jaring tetap terbuka dengan sempurna. Pelampung terbuat dari bahan plastik yang berbentuk bulat lonjong. Ada 2 jenis pelampung yang digunakan yaitu 1 pelampung besar, 12 pelampung kecil yang diikat pada tali ris atas.

(8) Pemberat

Pemberat berfungsi untuk penyeimbang/penenggelam supaya jaring bagian bawah tetap pada posisi. Pemberat terbuat dari bahan logam yang diikat dibagian tali ris bawah berbentuk bulat kecil. pemberat terbuat dari bahan logam, berat total logam yaitu $8 \mathrm{~kg}$.

(9) Besi

Besi terletak pada bagian tali segitiga, berfungsi sebagai penyeimbang sayap kanan dan kiri.

(10) Rantai

Rantai penghubung dari besi ke papan pembuka (otter board), terbuat dari bahan besi yang di hubungkan ke papan pembuka.

(11) Papan Pembuka (otter board)

Papan pembuka (otter board) terbuat dari bahan kayu yang dilekatkan dengan besi dan rantai. Berat masing-masing papan pembuka yaitu $17 \mathrm{~kg}$ dengan panjang $80 \mathrm{~cm}$ dan lebar $50 \mathrm{~cm}$. Papan pembuka (otter board) berfungsi sebagai pembuka dan pemberat supaya tetap dalam keadaan terbuka.

(12) Tali Penarik (bridle line)

Tali penarik berfungsi sebagai penarik pukat udang yang dihubungkan ke bagian buritan kapal. Tali penarik dengan panjang 90 meter bediameter $1,5 \mathrm{~cm}$.

\section{Komposisi Hasil Tangkapan}

Jumlah Hasil Tangkapan Berdasarkan Trip Penangkapan

Operasi penangkapan dilakukan sebanyak 3 kali trip penangkapan dengan enam kali setting, towing dan hauling. Pada operasi trip penangkapan ke 1 yaitu 1 kali hauling, operasi trip penangkapan ke 2 yaitu 2 kali hauling dan operasi trip penangkapan ke 3 yaitu 3 kali hauling. Untuk lebih jelasnya dapat dilihat pada gambar 3 berikut ini: 


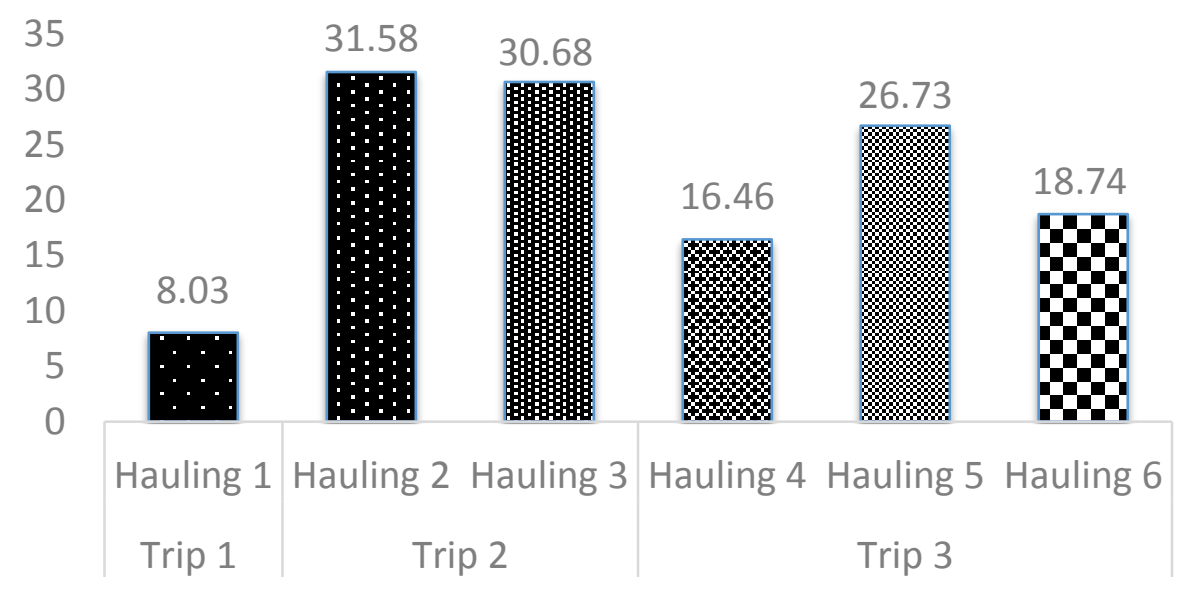

Gambar 3. Jumlah hasil tangkapan berdasarkan trip penangkapan

Dari gambar diatas dapat dilihat bahwa jumlah hasil tangkapan tertinggi terdapat pada trip penagkapan ke 2 yaitu pada hauling ke 2 sebesar $31,58 \mathrm{~kg}$ dan hauling ke 3 sebesar $30,68 \mathrm{~kg}$, dikarenakan pada trip penangkapan ke 2 cuaca pada saat operasi penangkapan relatif cerah sehingga pada saat operasi penangkapan dapat berjalan dengan lancar. Sedangkan jumlah hasil tangkapan terendah terdapat pada trip ke 1 sebesar $8,03 \mathrm{~kg}$. Pada saat operasi trip penangkapan ke 1 kondisi cuaca yang buruk atau terjadi badai pada saat penarikan (towing), menghindari kejadian yang tidak diinginkan para nelayan harus cepat melakukan pengangkatan (hauling) dan langsung pulang menuju muara tempat kapal-kapal bersandar. Sedangkan untuk operasi trip penangkapan ke 3 hasil tangkapan tertinggi terdapat pada hauling ke 5 sebesar $26,73 \mathrm{~kg}$. Pada operasi trip penangkapan ke 3 jumlah hasil tangkapannya lebih kecil dari trip penangkapan ke 2 karena pada saat operasi penangkapan dilaut, tinggi gelombang mencapai 6-10 meter membuat kapal yang di bawa tidak stabil dan terombang-ambing di laut. Melihat keadaan demikian, para nelayan memutuskan hanya melakukan penarikan (towing) dengan waktu yang relatif singkat dari pada biasanya yaitu hanya 1 jam penarikan disetiap hauling.

Dilihat dari gambar 4 berat hasil tangkapan yang didaratkan selama penelitian cukup bervariasi. Variasi yang terjadi pada hasil tangkapan pukat udang menurut Tiyoso (1979) vide Risamasu (2008) dalam Iskandar, (2011) karena diakibatkan oleh beberapa hal diantaranya adalah: 1) migrasi perubahan harian, musiman maupun tahunan dari kelompok ikan; 2) keragaman ukuran ikan dalam populasi (3) waktu penarikan (towing) pukat udang yang relatif singkat.

\section{Komposisi Jenis Hasil Tangkapan}

Total jenis hasil tangkapan yang terindetifikasi sebanyak 28 sepesies terdiri dari 5 kelompok organisme yaitu 16 spesies ikan, 8 spesies crustacea, 2 spesies moluska, 1 spesies Echinodermata, 1 spesies Coelenterata.

Komposisi hasil tangkapan berdasarkan total hasil tangkapan yang dimanfaat dan dibuang dapat dilihat pada Gambar 4 berikut ini : 


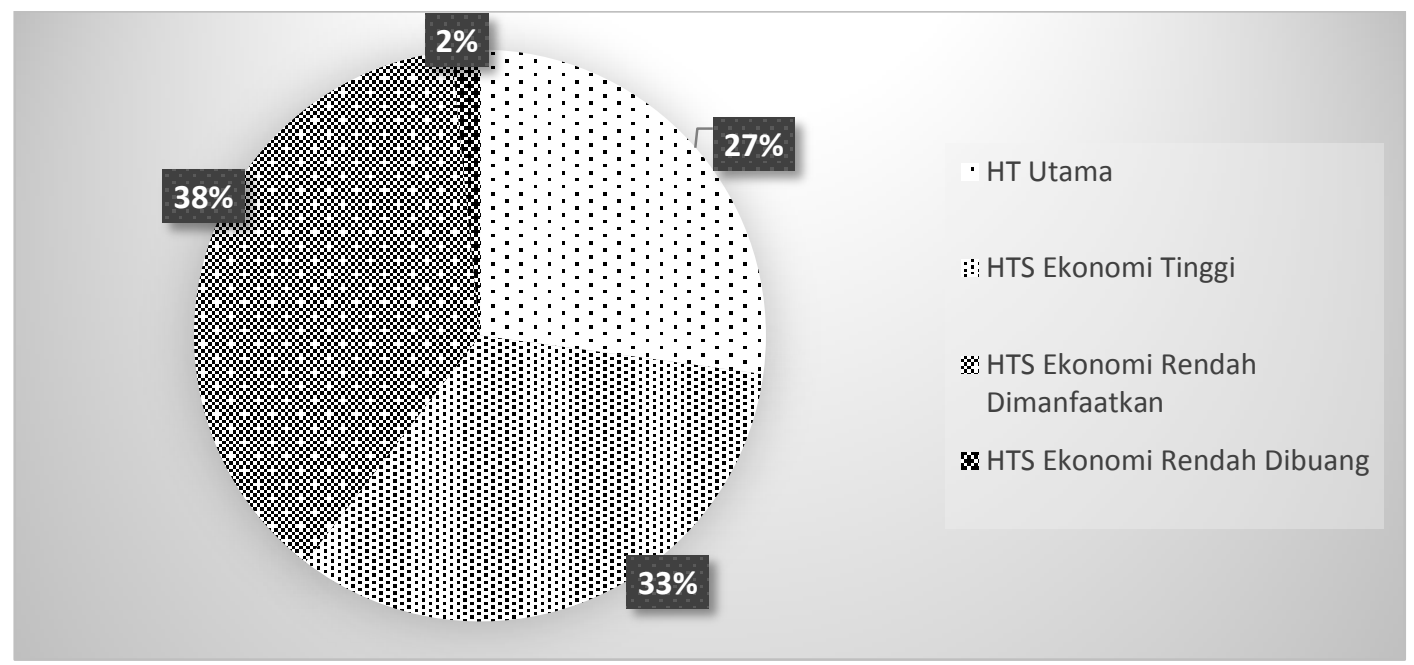

Gambar 4. Komposisi Total Hasil Tangkapan

Berdasarkan komposisi hasil tangkapan yang didaratkan di Perairan Desa

Pasar Bantal Kabupaten Mukomuko diketahui bahwa hasil tangkapan yang dibuang terdapat pada kategori hasil tangkapan sampingan ekonomis rendah. Hasil tangkapan ekonomis rendah yang dimanfaatkan sebesar $38 \%$ dan hasil tangkapan ekonomis rendah yang dibuang sebesar $2 \%$.

Kegiatan penangkapan menggunakan alat tangkap pukat udang (mini trawl) yang berada di Desa Pasar Bantal masih tergolong tradisional atau perikanan skala kecil perlu dilakukan monitoring atau pencatatan hasil tangkap yang didaratkan mengingat persentase hasil tangkapan sampingan yang dibuang sangat kecil. Sehingga data dari ikan-ikan yang didaratkan sudah dapat mewakili kondisi hasil tangkapan dari perikanan mini trawl skala kecil yang berada di Perairan Desa Pasar Bantal.

Komposisi total hasil tangkapan berdasarkan dari 5 kelompok organisme yaitu ikan 74,58 kg (56 \%), Crustacea 51,16kg (39\%), Moluska 5,21 kg (4\%), Coelenterata $0,84 \mathrm{~kg}(1 \%)$, Echinodermata $0.43 \mathrm{~kg}(0,3 \%)$. Tingginya hasil tangkapan seperti jenis organisme ikan dan crustacea dapat disebabkan karena:

1) Alat tangkap Pukat udang memiliki sifat aktif yaitu mengejar target ikan dengan cara ditarik oleh kapal sehingga banyak ikan yang bukan menjadi target penangkapan ikut tertangkap (Manadiyanto et al., 2000)

2) Perairan yang dangkal merupakan tempat ikan mencari makan (feeding ground), pemijahan (spawning ground) dan pemeliharaan (nursery ground). Sehingga banyak ikan-ikan muda (berukuran kecil) yang ikut tertangkap (Riyanto, 2005).

3) Pengoperasian pukat udang tidak diikuti pemasangan By Catch Reduction Device (BRD), sehingga jumlah ikan yang bukan menjadi target penangkapan banyak tertangkap (Chalimi, 2005).Komposisi hasil tangkapan berdasarkan kelompok organisme dapat dilihat pada gambar 5 berikut ini: 


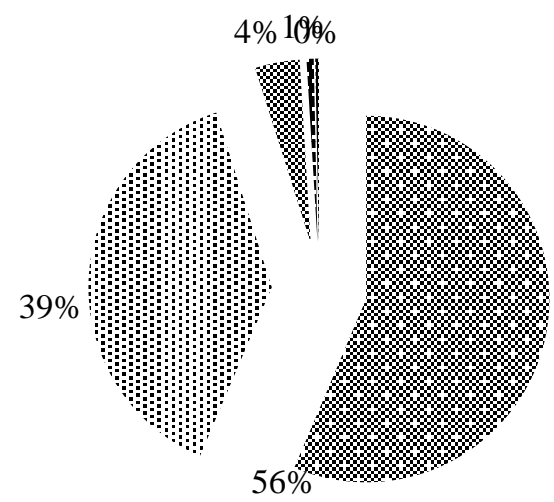

æ Ikan

Crustacea

Moluska

a Coelenterata

8 Echinodermata

Gambar 5. Komposisi Hasil Tangkapan Berdasarkan Kelompok Organisme (data primer)

\section{Komposisi Berat Hasil Tangkapan}

Berdasarkan pengamatan dilapangan berat hasil tangkapan yang didaratkan dari unit penangkapan pukat udang (mini traw) dikelompokkan dalam dua kategori, yaitu hasil tangkapan utama dan hasil tangkapan sampingan. Komposisi berat hasil tangkapan utama disajikan pada Gambar 6 berikut ini :

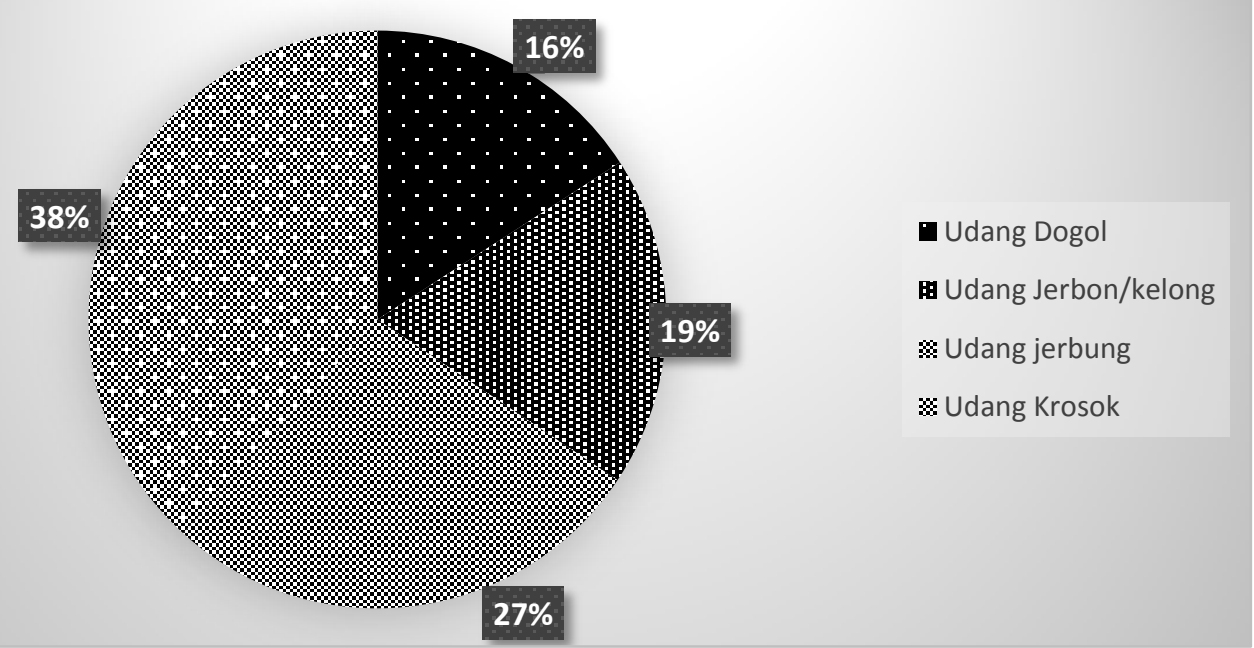

Gambar 6. Komposisi Hasil Tangkapan Utama

Berdasarkan gambar 6 diketahui bahwa jumlah hasil tangkapan utama yang diperoleh selama penelitian dengan 6 kali hauling sebanyak 4 spesies udang yang terdiri dari udang dogol (Metapenaeus ensis), udang Jerbon/kelong (Metapenaeus monoceros), udang Jerbung (Panaeus meruiensis), dan udang kerosok (Parapenaeopsis sculptilis) dengan berat total 35,91 kg (27,15\%). Hasil tangkapan utama yang mendominasi yaitu udang kerosok Parapenaeopsis sculptilis) yaitu sebesar $38 \%$ hidup pada kedalaman 15-30 meter dan udang jerbung (Panaeus merguensis) yaitu 27\% hidup pada kedalam 15-60 meter.

Komposisi Hasil Tangkapan Sampngan Ekonomis Tinggi

Berdasarkan pengamatan selama penelitian komposisi hasil tangkapan sampingan ekoomis tinggi dapat dilihat pada gambar 7 berikut ini: 


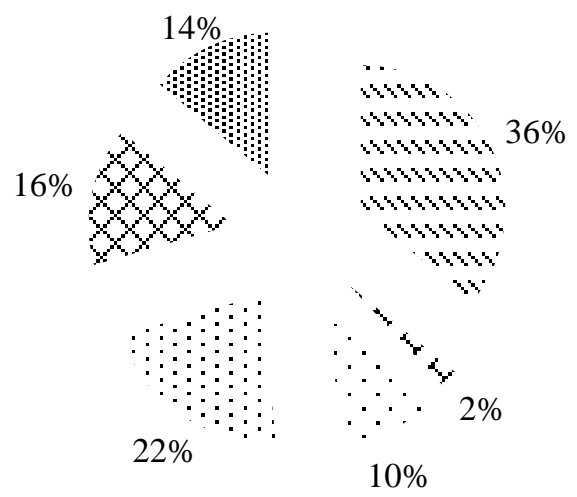

$$
\begin{aligned}
& \text { "Layur } \\
& \text { Pari } \\
& \text { Sotong } \\
& \text { : Rajungan } \\
& \triangle \text { Bawal Putih } \\
& \text { : Tigawaja }
\end{aligned}
$$

$10 \%$

Gambar 7. Komposisi Hasil Tangkapan Sampingan Ekonomis Tinggi

Jumlah hasil tangkapan sampingan yang bernilai ekonomis tinggi sebanyak 5 spesies yang terdiri dari beledang/layur (Trichiurus savala), pari (Gymnura poecilura), sotong (Sepia apama), rajungan (Portonus spp), bawal putih (Pampus argenteus), tiga waja (Pennahia argentata) dengan berat total $44,01 \mathrm{~kg}(34,25 \%)$. Tertangkapnya jenis ikan bawal putih (Pampus argenteus) karena kebiasaan hidup yang bergerombol (schooling) di kolom perairan hal ini sama dengan pendapat (Partosuwiryo, 2008) Ikan bawal putih hidup bergerombol di dasar perairan atau kolom air perairan dekat pantai sampai kedalaman $100 \mathrm{~m}$, makanan ikan ini berupa ikan-ikan kecil. Munculnya jenis ikan ini juga berkaitan dengan adanya penyuburan daerah pantai seiring datangnya musim hujan.

\section{Komposisi Hasil Tangkapan Sampingan Ekonomis Rendah}

Berdasarkan Pengamatan selama penelitian, komposisi hasil tangkapan sampingan ekonomis rendah dapat dilihat pada Gambar 8 berikut ini:

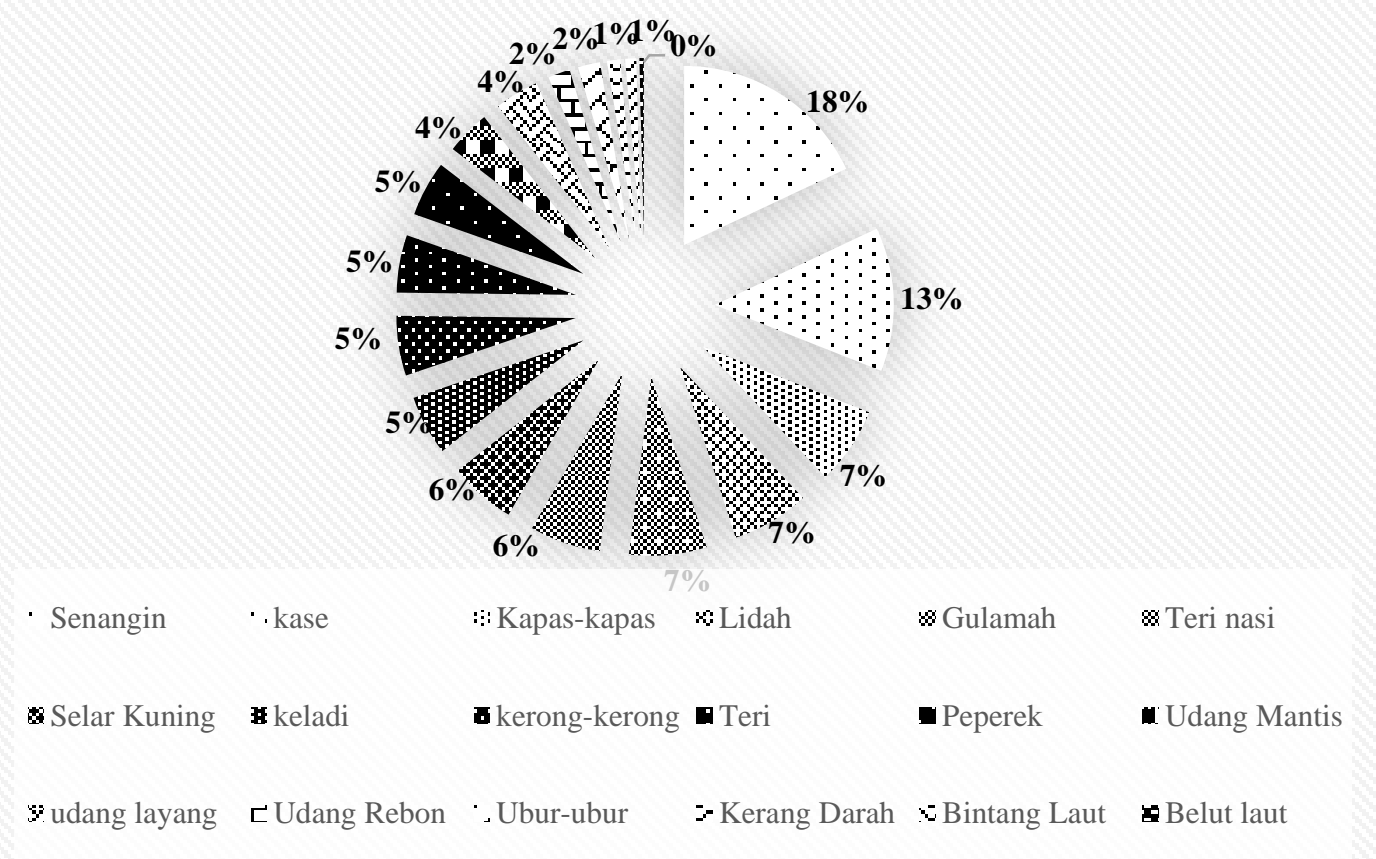

Gambar 8. Komposisi Hasil Tangkapan Sampingan Ekonomis Rendah 
Jumlah hasil tangkapan sampingan yang bernilai ekonomis rendah sebanyak 18 spesies dengan hasil tangkapan yang mendominasi adalah ikan senangin (Eleutheronema tetradactyum) $9,16 \mathrm{~kg}(17,51 \%)$, dengan berat total dalam kelompok $52,3 \mathrm{~kg}(39,55 \%)$, dari jumlah total hasil tangkapan sebesar $132,22 \mathrm{~kg}$. Mahiswara (2004) menyebutkan bahwa sumberdaya ikan demersal yang mendiami wilayah paparan atau perairan dekat pantai memiliki keanekaragaman hayati yang tinggi dibandingkan dengan ikan pelagis.

Jenis sumberdaya ikan demersal ini tidak saja kelompok ikan, namun juga kelompok non ikan seperti moluska, crustacea, colenterata, dan echinodermata. Selain jenis ikan demersal, dalam komposisi hasil tangkap sampingan juga terdapat jenis ikan pelagis. Tertangkapnya ikan-ikan pelagis disebabkan beberapa faktor. Salah satu faktor penyebabnya adalah perairan dangkal tempat pengoperasian pukat udang merupakan habitat ikan-ikan pelagis kecil tersebut. Walaupun ikan-ikan tersebut tidak berasosiasi langsung dengan dasar perairan, namun secara alamiah ikan pelagis akan mencari makan ke kolom dan dasar peraairan. Ikan-ikan pelagis tersebut dapat tertangkap pada saat hauling atau jaring sedang ditarik ke permukaan (Riyanto, 2005). Tertangkapnya jenis udang mantis diketahui bahwa Udang mantis dapat hidup di air laut maupun air payau,dan sering dijumpai di daerah pesisir maupun pertambakan. Habitat sebagian besar udang mantis adalah pantai, senang hidup di dasar air terutama pasir berlumpur (Astuti dan Ariestyani, 2013).

\section{Komposisi Hasil Tangkapan Berdasarkan Nilai Ekonomi}

Komposisi hasil tangkapan berdasarkan nilai ekonomi dilihat dari harga pasar lokal dengan melalui wawancara langsung dilapangan.

Pada dasarnya ada beberapa hasil tangkapan sampingan ekonomis rendah tidak sesuai dengan harga jual yang terdapat pada harga jual pasar didaerah-daerah lain pada umumnya. Salah satunya adalah udang mantis (Squalameteus spp) atau udang kacix lapik (nama derah) yang harganya di Pasar Bantal hanya Rp 2.500 /kg yang dicampur dengan ikan rucah lainnya, sangat beerbeda dengan didaerah lain. Menurut (Astuti dan Ariestyani, 2013) Beberapa spesies udang mantis dikenal sebagai bahan makanan eksotis dan sebagai komoditas ekspor. Jenis-jenis udang mantis yang bernilai ekonomi tinggi adalah dari famili Harpiosquillidae dan Squillidae. Harga jual udang mantis di Daerah Jakarta Selatan dilihat dari berbagai ukuran. Jika dalam keadaan hidup, Ukuran 6 inchi Rp 10.000 /ekor, ukuran 11 inchi Rp 80.000 /ekor, >11 inchi bisa mencapai Rp 100.000 /ekor sedangkan dalam keadaan mati udang mantis dijual dengan harga $\mathrm{Rp}$ 45.000,- / kg.

\section{Pemasaran Hasil Tangkapan}

Hasil tangkapan pukat udang (mini traw) yang didapatkan oleh nelayan di Pasar Bantal umumnya dijual kepada pengepul atau pengusaha perikanan yang ada di pangkalan pendaratan ikan (PPI) Pasar Bantal. Hasil tangkapan ada yang dijual di pasar setempat dan ada juga yang di jual ke daerah Jakarta, Kota Mukomuko, Kota Padang, Kota Bengkulu dan daerah lainnya. Hasil tangkapan utama berupa udang dan hasil tangkapan sampingan yang bernilai ekonomis tinggi berupa jenis - jenis ikan-ikan tertentu dijual dengan harga bervariasi tergantung jenis, ukuran dan kualitas yang ada. 
Rantai pemasaran hasil tangkapan pukat udang (mini trawl) di Desa Pasar Bantal dapatdilihat padagambar berikut ini :

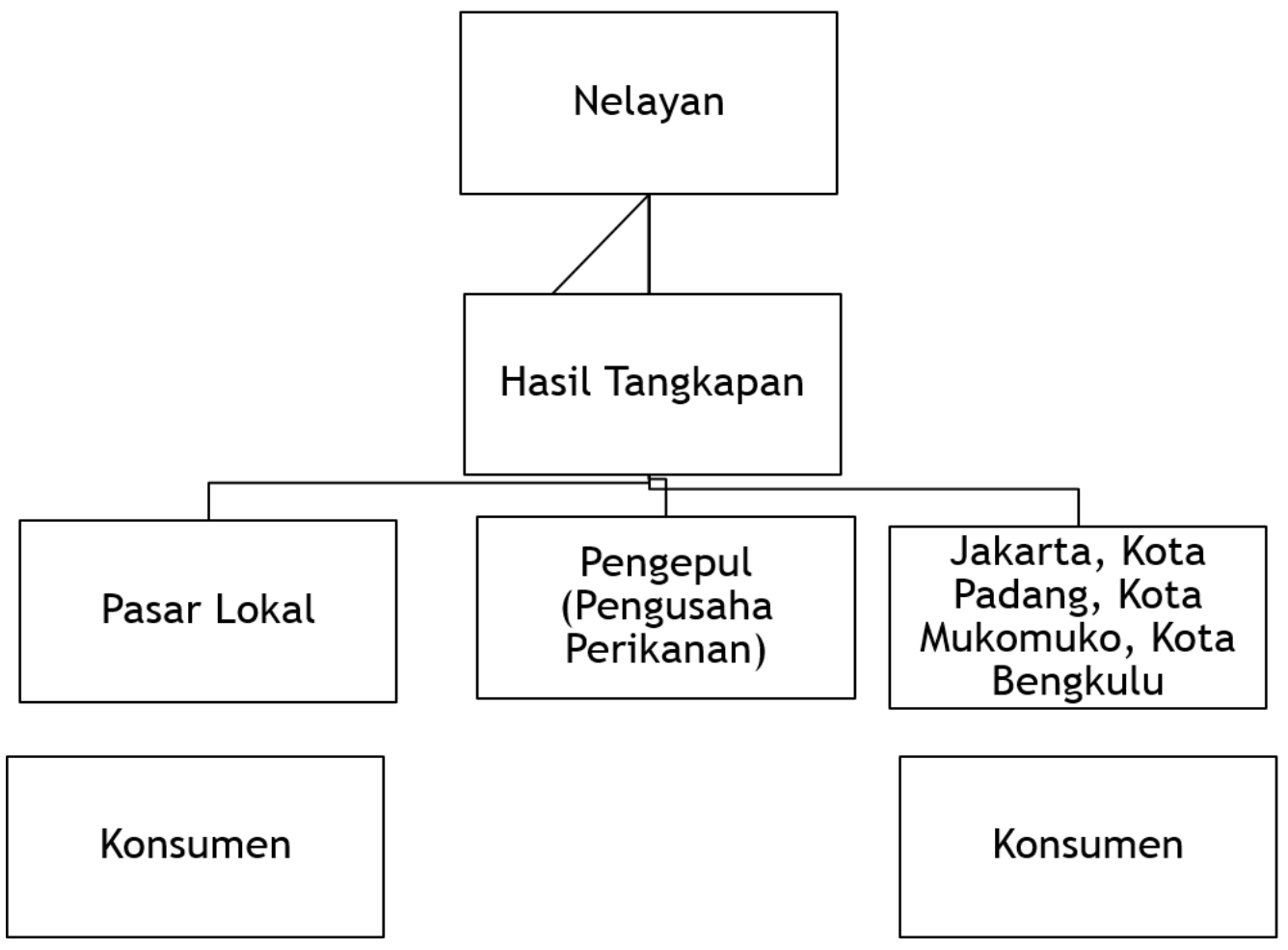

Gambar 9. Rantai Pemasaran

\section{Alternatif Pengelolaan}

Alternatif pengelolaan untuk mengurangi hasil tangkapan sampingan (Bycatch) dapat dilakukan dengan input kontrol yaitu pengaturan daerah penangkapan pukat udang untuk perikanan pukat udang (mini trawl) skala kecil. Teknologi penangkapan ikan melalui pemasangan bycatch reduction device (BRD) yang sesuai untuk perikanan demersal trawl skala kecil (Djazuli $d k k$, 2005). Menggunakan BRD ada beberapa faktor yang diperhatikan termasuk faktor modifikasi dari BRD yang harus memenuhi persyaratan terutama dalam mengurangi hasil tangkapan sampingan dari perikanan mini trawl skala kecil di perairan laut Pasar Bantal Kabupaten Mukomuko.

Penutupan wilayah penangkapan merupakan salah satu cara yang efektif untuk mengurangi hasil tangkapan sampingan dan ikan-ikan yang berukuran kecil dari spesies yang bukan merupakan tujuan utama penangkapan. Penutupan musim penangkapan dilakukan dengan memberlakukan waktu tertentu untuk melakukan penangkapan sedangkan penutupan wilayah penangkapan dilakukan dengan melarang dilakukannya aktifitas penangkapan pada suatu wilayah tertentu (Caddy, 1982 dalam Wahju 2012).

Pemanfaatan hasil tangkapan sampingan ekonomis rendah di Pangkalan Pendaratan Ikan (PPI) Pasar Bantal Kabupaten Mukomuko masih belum optimal yaitu hanya dijadikan untuk pakan umpan ayam dijual dengan harga $\mathrm{Rp}$ 3.000,- / kg untuk itu perlu dilakukan pemanfaatan yang optimal dengan cara pengolahan dalam bentuk skala industri. Salah satu teknologi pengolahan yang 
sesuai adalah teknologi pengolahan surimi. Surimi merupakan konsentrat dari protein miofibrilar yang mempunyai kemampuan pembentukan gel, pengikatan air, pengikat lemak dan sifat-sifat fungsional yang baik digunakan sebagai bahan baku untuk produk baso, sosis, otak-otak dan sebagainya yang spesifikasinya menuntut kemampuan dalam pembentukan gel (Ramirez et al.2002).Program monitoring dalam perikanan pukat udang skala kecil di perairan laut Pasar Bantal Kabupaten Mukomuko yaitu diperlukan adanya suatu identifikasi yang kontinyu untuk mengestimasi spesies ikan yang tertangkap. Data tersebut meliputi speses yang dikategorikan sebagai komersial dan spesies yang tidak dimanfaaatkan (discard). Estimasi setiap tahun untuk hasil tangkapan sampingan yang dimanfaatkan dan yang dibuang ke laut. Tujuan dari program monitoring ini adalah untuk menyediakan informasi dalam kuantitas, ukuran dan komposisi umur dari ikan-ikan yang dimanfaatkan dan ikan-ikan yang dibuang kelaut.

\section{KESIMPULAN}

Berdasarkan dari hasil tangkapan yang diikuti langsung dilapangan selama penelitian dengan 6 kali hauling yaitu Jumlah hasil tangkapan utama sebanyak 4 spesies udang yang terdiri dari udang dogol (Metapenaeus ensis), udang jerbon/kelong (Metapenaeus monoceros), udang jerbung (Panaeus merguiensis), dan udang kerosok (Parapenaeopsis sculptilis) dengan berat total $35,91 \mathrm{~kg}(27,15 \%)$ yang didominasi oleh udang kerosok (Parapenaeopsis sculptilis) $13,74 \mathrm{~kg}$.

Jumlah hasil tangkapan sampingan yang bernilai ekonomis tinggi sebanyak 6 spesies yang terdiri dari layur (Trichiurus savala), pari (Gymnura poecilura), sotong (Sepia apama), rajungan (Portonus spp), bawal putih (Pampus argenteus) tiga waja (Pennahia argentata) dengan berat total $44,01 \mathrm{~kg}$ $(33,28 \%)$ didominasi oleh layur (Trichiurus savala) sebesar 15,81 kg. Sedangkan untuk jumlah hasil tangkapan sampingan yang bernilai ekonomis rendah terdapat sebanyak 18 spesies dengan berat total $52,3 \mathrm{~kg}(39,55 \%)$ didominasi oleh senangin (Eleutheronema tetradactyum) $9,16 \mathrm{~kg}$ dari jumlah hasil tangkapan total sebesar 132,22 kg.

Jenis hasil tangkapan yang terindetifikasi sebanyak 28 sepesies terdiri dari 5 kelompok organisme yaitu 16 spesies ikan, 8 spesies Crustacea, 2 spesies moluska, 1 spesies Echinodermata, 1 spesies Coelenterata.

\section{DAFTAR PUSTAKA}

Astuti, I R dan Ariestyani, F. 2013. Potensi dan Prospek Ekonomis Udang mantis Di Indonesia. Pusat Penelitian dan Pengembangan Perikanan Budidaya. Jakarta. 6 hal.

Chalimi, M. 2005. Pemasangan By-Catch Reduction Device Pada Jaring Arad (Mini Trawl): Pengaruhnya Terhadap Hasil Tangkapan dan Selektivitas Hasil Tangkap Sampingan Dominan. Skripsi (tidak dipublikasikan). Program Studi Pemanfaatan Sumberdaya Perikanan. Fakultas Perikanan dan Ilmu Kelautan. Institut Pertanian Bogor.

Djazuli N, Wahyuni M, Monitja D, Purbayanto A. Modifikasi Teknologi Pengolahan Surimi Dalam Pemanfaatan "ByCatch" Pukat Udang Di Laut Arafura. Bogor: IPB. 14 hal. 
(FAO). 1974. Spesies Identification Sheets For Fishery Purposes. Eastern Indian Ocean (Fishing Area 57) and Western Central Pacific (Fishing Are 71). Rome.

(FAO). 2012. Field Identificaton Guide to the Living Marine Resource of Kenya. FAO of the Limited National. Rome 357P.

Hall,M.A.1999.The effects of Fishing and Marine Ecosystem and Communities.Blackwell Science Ltd.London.

Iskandar,D. 2011. Analisis Hasil Tangkapan Sampingan Bubu yang Dioperasikan Di Perairan Karang Kepulauan Seribu. Jurnal Saintek Perikanan. Bogor : FPIK,IPB.

Khaerudin, A. 2006. Proporsi Hasil Tangkapan Jaring Arad (Mini trawl) yang Berbasis di Pesisir Utara, Kota Cirebon. [Skripsi] (tidak dipublikasikan). Bogor: PSP, FPIK, IPB.

Manadiyanto, H, H. Latif, dan S. Iriandi. 2000. Status Penangkapan Udang Penaeid Pasca Pukat Harimau di Perairan Laut Jawa. Jakarta: Balai Penelitian Perikan-an Laut.

Nelson, J.S., 1984. Fishes of the world. 2 end edition. A Wiley Interscience Publication. John Wiley and Fous. Newyork. Chichester. Brisbane. Toronto. Singapore. 523P.

Partosuwiryo, S. 2008. Alat Tangkap Ikan Ramah Lingkungan. Penerbit Citra Aji Pratama. Yogyakarta.

Ramirez JA, Garcia-Carreno FL, Morales OG, Sanchez A. 2002. Inhibition of modorias sociated protein ases by legume seed extract in surimi production. Journal Food Science 67(2):578-581.

Riyanto. M. 2005. Pengoperasian Pukat Udang Pada Siang dan Malam Hari: Pengaruhnya Terhadap Hasil Tangkap Sampingan di Laut Arafura. Skripsi (tidak dipublikasikan). Program Studi Pemanfaatan Sumberdaya Perikanan. Fakultas Perikanan dan IImu Kelautan. Institut Pertanian Bogor. $70 \mathrm{Hal}$.

Wahju I.R. 2012. Kajian Perikanan Trawl Demersal : Evaluasi Tiga Jenis Bycatch Reduction Device (BRD). Bogor. PSP, FPIK, IPB. 207 hal. 